\title{
Correction to: The North African coastal low level wind jet: a high resolution view
}

\author{
Pedro M. M. Soares ${ }^{1}$ - Daniela C. A. Lima ${ }^{1}$. Álvaro Semedo ${ }^{2} \cdot$ Rita M. Cardoso $^{1} \cdot$ William Cabos $^{3} \cdot$ Dmitry Sein $^{4,5}$
}

Published online: 30 October 2018

(c) The Author(s) 2018

\section{Correction to: Climate Dynamics \\ https://doi.org/10.1007/s00382-018-4441-7}

The article The North African coastal low level wind jet: a high resolution view, written by Pedro M. M. Soares, Daniela C. A. Lima1, Álvaro Semedo, Rita M. Cardoso, William Cabos and Dmitry Sein, was originally published electronically on the publisher's internet portal (currently SpringerLink) on 15 September 2018 without open access.

With the author(s)' decision to opt for Open Choice the copyright of the article changed on 16 October 2018 to $($ ) The Author(s) 2018 and the article is forthwith distributed under the terms of the Creative Commons Attribution 4.0 International License (http://creativecommons.org/licenses/ by/4.0/), which permits use, duplication, adaptation, distribution and reproduction in any medium or format, as long as you give appropriate credit to the original author(s) and the source, provide a link to the Creative Commons license and indicate if changes were made.

Open Access This article is distributed under the terms of the Creative Commons Attribution 4.0 International License (http://creativeco mmons.org/licenses/by/4.0/), which permits unrestricted use, distribution, and reproduction in any medium, provided you give appropriate credit to the original author(s) and the source, provide a link to the Creative Commons license, and indicate if changes were made.
The original article can be found online at https://doi.org/10.1007/ s00382-018-4441-7.

\section{Pedro M. M. Soares}

pmsoares@fc.ul.pt

1 Instituto Dom Luiz (IDL), Faculdade de Ciências, Universidade de Lisboa, Campo Grande, Ed. C8 (3.26), 1749-016 Lisbon, Portugal

2 Department of Water Science and Engineering, IHE Delft, Delft, The Netherlands

3 Department of Physics, University of Alcalá, Alcalá de Henares, Madrid, Spain

4 Alfred Wegener Institute for Polar and Marine Research, Am Handelshafen 12, 27568 Bremerhaven, Germany

5 Shirshov Institute of Oceanology, Russian Academy of Science, 36 Nahimovskiy Prospect, Moscow 117997, Russia 